\title{
Soil Compaction Effects on the Establishment of Three Tropical Tree Species
}

\author{
Rebecca Tirado-Corbalá and Brian K. Slater
}

\begin{abstract}
Tree seedlings planted in containers along sidewalks in urban environments show restricted growth and development over time. This is the result of limited soil volume and soil compaction that hampers nutrient availability and water movement. Using tree species commonly used in urban forestry in Puerto Rico, this study was conducted to determine their growth response when planted in compacted soils. Seedlings of three ornamental tropical tree species, trumpet bush [Tecoma stans (L.) Juss. ex Kunth], bottle brush [Callistemon citrinus (Curtis) Skeels], and pink trumpet (Tabebuia rosea $\mathrm{dc}$.) were transplanted into pots of sandy clay loam or clay soils at three levels of compaction: control (no compaction), $1.2 \mathrm{~g} / \mathrm{cm}^{3}$ and $1.4 \mathrm{~g} /$ $\mathrm{cm}^{3}$ bulk density, respectively. Plant height, shoot diameter, leaf number and color, foliar area, and root, shoot, and leaf dry weights were measured on two plants every two months for six months. All species exhibited better growth in sandy clay loam at $1.2 \mathrm{~g} / \mathrm{cm}^{3}$; after six months, all species showed a reduced root-shoot ratio. When planted in clay at $1.4 \mathrm{~g} / \mathrm{cm}^{3}$, all trumpet bush seedlings died within two months. No leaf color differences were observed between species at different compaction levels. Bottle brush showed less growth suppression by increasing compaction level in both soils.

Key Words. Callistemon citrinus; Root Growth; Root-Shoot Ratio; Tabebuia rosea; Tecoma stans; Tree Establishment; Urban Forestry; Urban Soils.
\end{abstract}

Trees planted in urban environments often encounter myriad problems, both biophysical and those attributable to human activities such as lack of management and vandalism. Biophysical problems are numerous and include transplant stress (Waring and Schlesinger 1985), soil compaction (Patterson 1977; Craul 1992), water stress, high soil temperature (Craul 1992), high pH, soil salinity, poor soil drainage (Kozlowski, 1985; Kelsey and Hootman 1990; Craul 1992), root volume reduction (Lindsey and Bassuk 1991), root loss during tree transplant (Waring and Schlesinger 1985), increase of vapor pressure deficit caused by urban microclimate and reflected heat (Bassuk and Whitlow 1988; Kjelgren and Clark 1993), and eventually, increase in mortality. Thus, arborists and horticulturists have the challenge of establishing trees under less than optimal conditions for root growth (Neal and Whitlow 1997). Tree establishment in urban areas requires an understanding not only of the physiological and biological factors but also institutional factors such as legislation and planning, which are necessary for the development of urban forest landscapes (Bradley 1995). Urban soils are often the result of severe disturbance and alterations by processes associated with the development of urban infrastructure (Craul 1992).

Soil compaction occurs from pressure applied to the land surface during the construction of new buildings and roads. Compaction occurs either deliberately or as an unintended consequence of construction. Deliberate compaction is imposed to ensure physical soil stability for structures; unintended compaction results from such inadvertent activity as vehicular or pedestrian traffic (Randrup 1997). Compaction changes the physical properties of the soil, increasing the bulk density and strength, and decreasing total porosity (Patterson 1977). Compaction causes a reduction in water and oxygen infiltration as well as drainage. These altered properties inhibit woody plant growth and significantly reduce shoot growth (Chiapperini and Donnelly 1978). Altered soil properties have been shown to be the primary factors in sugar maple (Acer saccharum) decline in urban areas (Ruark et al. 1983). Furthermore, dense soil offers greater resistance to root development (Foil and Ralston 1967; Patterson et al. 1980; Lindsey and Bassuk 1991; Handreck and Black 1994).

Inadequate soil root space in compacted soils is the major factor causing premature mortality of trees in urban areas (Patterson et al. 1980; Krizek and Dubik 1987; Jim 1998). There is a conflict between the biological needs of trees whose roots generally spread laterally near the surface and the requirements for construction. In the urban environment, a tree is often confined to a street tree pit, narrow parkways or above-ground planters, which restrict the rooting area, slow or halt root penetration, and increase branching and radial thickening of the roots (Materechera et al. 1991). These confined situations may allow the roots to spread laterally but only for very short distances.

Different soil textures and poor soil structure, together, play a major role in the growth of tree roots (Craul 1985; Day and Bassuk 1994). A clay soil may have a bulk density of approximately $1.4 \mathrm{~g} / \mathrm{cm}^{3}$, whereas sandy soils may have a bulk density of $1.7 \mathrm{~g} / \mathrm{cm}^{3}$ or higher.

Species vary in their ability to penetrate compacted soil, partially due to different soil textures (Zisa et al. 1980; Pan and Bassuk 1985; Day and Bassuk 1994). Root growth of Forsythia ovata was significantly restricted at bulk densities as low as $1.2 \mathrm{~g} / \mathrm{cm}^{3}$ (Alberty et al. 1984). In a container experiment, sugar maple seedling roots were evenly distributed throughout the pot for uncompacted soils, while the roots were confined to the upper portion of the pot in higher bulk density soils. At a 
bulk density of $1.4 \mathrm{~g} / \mathrm{cm}^{3}$, the roots were few and confined to the upper one-third of the pot (Chiapperini et al. 1978). Rooting can therefore be restricted by moderate soil compaction for particular soil textures. Zisa et al. (1980) found that depth of root penetration for Pinus nigra in sandy loam soil was reduced at a bulk density of $1.6 \mathrm{~g} / \mathrm{cm}^{3}$, but at $1.4 \mathrm{~g} / \mathrm{cm}^{3}$ Pinus nigra were severely restricted in silt loam soils. For Ailanthus altisima the root growth and penetration in sandy loam was significantly restricted at a bulk density of $1.64 \mathrm{~g} / \mathrm{cm}^{3}$, with similar restriction in sandy soil at $1.7 \mathrm{~g} / \mathrm{cm}^{3}$ (Pan and Bassuk 1985).

The objective of this study was to evaluate the growth and development of three tree species during the first six months after being transplanted at different levels of compaction in two soil types. As a working hypothesis, it was expected that trees growing in denser clay soils would have less ability to overcome higher mechanical impedance and strength of compacted soils than looser sandy clay loam soils. The three tree species evaluated are in common use in urban forestry in Puerto Rico.

\section{MATERIALS AND METHODS}

The study was conducted on Alzamora Farm of the Agricultural Science Faculty at the University of Puerto Rico-Mayagüez (UPRM) (Mayaguiez, Puerto Rico) in 2003-2004. Alzamora Farm is located at $18^{\circ} 12^{\prime} 54.3^{\prime \prime} \mathrm{N}$ and $67^{\circ} 08^{\prime} 43.3^{\prime \prime} \mathrm{W}$. The average annual temperature was $25^{\circ} \mathrm{C}$ with little monthly variation. The annual average precipitation was $3,200 \mathrm{~mm}$, with a dry season from December to April (monthly average rainfall $68 \mathrm{~mm}$ ), and a rainy season from July to September [monthly average rainfall $202.4 \mathrm{~mm}$ (ATMOS CARIB 2003)].

Callistemon citrinus [(Curtis) Skeels], commonly known as red bottlebrush, is native to Australia and grows easily in tropical and subtropical regions. It is a small tree or large shrub that grows 2-4 $\mathrm{m}$ tall and 2-3 m wide, and likes well-drained soils, preferably sandy loam soils, but is quite adaptable. Red bottlebrush tolerates any soil except very poor or alkaline soils (Gilman and Watson 1993).

Tecoma stans [(L.) Juss. ex Kunth], commonly known as trumpet brush, is a native tree from the Caribbean (Little and Wadsworth 1964), naturalized in much of the tropical and subtropical regions. It is a medium-size brush, $1.5-1.7 \mathrm{~m}$, with many branches and basal stems. Trumpet bush can grow well in $\mathrm{pH} \mathrm{6.0-7.8} \mathrm{and} \mathrm{in} \mathrm{most}$ well-drained soils, including calcareous fill, infertile sands, acidic Ultisols and volcanic regolith. The species is described as a "water spender," which is able to convert to a water saver (Tipton 1994).

Tabebuia rosea $(\mathrm{dc})$, commonly known as pink trumpet, is native of tropical continental America, and grows from wet lowlands to dry uplands, from southern Mexico to Venezuela (Gentry 1992). The pink trumpet is a medium-sized tree with medium to fast growth (Whitmore and Hartshorn 1969; Salas-Estrada 1993). Pink trumpet is found in deep and superficial soils, but grows better in well-drained soils with a light texture (Gentry 1992). Pink trumpet can grow well in pH 5.5 to 8.0, in sandy loam to clay loam soils.

Field observations suggest the three tree species tested have the following order of tolerance to urban soil conditions including compaction: T. stans $>T$. rosea $>C$. citrinus.

Same-size seedlings $47 \mathrm{~cm}$ in height of three ornamental tropical tree species; trumpet bush, bottle brush, and pink trumpet were transplanted in $18.52 \mathrm{~L}$ pots of sandy clay loam or clay at three levels of compaction: control (no compaction), medium compaction with a bulkdensity of $1.2 \mathrm{~g} / \mathrm{cm}^{3}$, and high compaction $1.4 \mathrm{~g} / \mathrm{cm}^{3}$ bulkdensity.
Plant height, trunk shoot diameter, leaf number and color, foliar area, and leaf, shoot, and root dry weight were measured on two plants every two months during six months. The seedlings of the three ornamental tropical tree species were donated by the Department of Natural Resources of Puerto Rico's Arecibo Nursery. The seedlings were acclimatized in a nursery located inside of Alzamora Farm at UPRM Campus.

\section{Construction of the Compacted Soils}

Tree seedlings planted in containers along sidewalks or in sidewalks in urban environments show restricted growth over time due to compacted and limited soil volumes. For this reason the study authors chose a compaction approach of using a Proctor test hammer to achieve consistent bulk density through each whole pot.

A sandy clay loam soil $(45.3 \%$ sand, $25.9 \%$ silt, and $28.8 \%$ clay) of $\mathrm{pH} 7.1$ and $1.5 \%$ organic matter (O.M.), and a clay soil (2.1\% sand, $17.4 \%$ silt, and $80.5 \%$ clay) of $\mathrm{pH} 4.7$ and $2.5 \%$ O.M., were used to construct the compacted soils. Prior to compaction, both soils were brought to $20 \%$ volumetric moisture content. Desired bulk densities were obtained by compacting different weights of soil to a single volume, applying different numbers of blows to the soil with a hammer of $2.5 \mathrm{~kg}$ with a free fall of $30.4 \mathrm{~cm}$ used in ASTM Proctor tests (Felt 1965).

The soil was compacted in $18.52 \mathrm{~L}$ pots with an upper internal diameter of $28.9 \mathrm{~cm}$, a lower internal diameter of $26 \mathrm{~cm}$, and height of $36.5 \mathrm{~cm}$. The soil was poured inside the $18.52 \mathrm{~L}$ pots and compacted to achieve different levels of compaction (different bulk density values). After the compacted soil reached a depth of $24.2 \mathrm{~cm}$ in each pot, a metallic pot with an internal diameter of $15.9 \mathrm{~cm}$ and height of $15.2 \mathrm{~cm}$ created with metallic mesh $(1.3 \mathrm{~cm} \times 2.5 \mathrm{~cm})$ (Figure 1a; Figure 1b) was placed in the center of the $18.52 \mathrm{~L}$ pots. Inside this metallic mesh pot PVC tubes $(15.3 \mathrm{~cm} \times 15.3 \mathrm{~cm})$ were inserted with almost the same dimensions of the metallic pots to ensure the level of compaction and avoid loss of soil inside the metallic mesh pots. After the metallic pot with the PVC tubes were placed in the center of the $18.52 \mathrm{~L}$ pots, more soil was poured around the metallic pot and the soil was compacted further (Figure 1c).

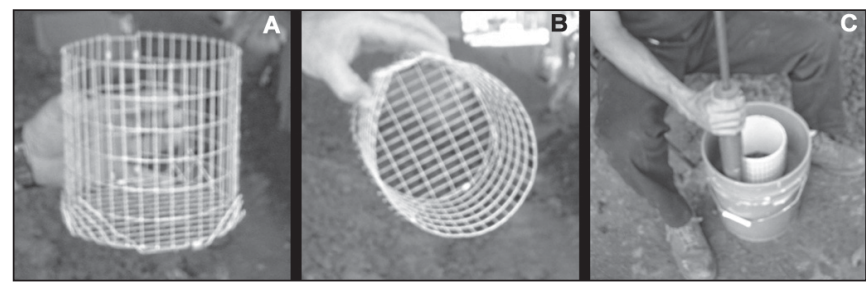

Figure 1. Construction of metallic pot with a metallic mesh (1.27 $\mathrm{cm} \times 2.54 \mathrm{~cm}$ ); (a) height (15.2 cm), and (b) Internal diameter (15.9 $\mathrm{cm})$. After a PVC pipe was placed inside of the metallic pot, the PV pipe with the pot were placed in the center of the $18.52 \mathrm{~L}$ item and the soil was compacted using a hammer, (c), of $2.5 \mathrm{~kg}$ with a free fall of $30.4 \mathrm{~cm}$ used in ASTM Proctor test.

Once desired levels of compaction were achieved, the PVC tubes were removed and seedlings were planted inside the metallic mesh (Figure 2a; Figure 2b). The same soil type was used to fill the remaining empty space inside the metallic pot (Figure $2 \mathrm{c}$ ). To obtain a bulk density value of $1.2 \mathrm{~g} / \mathrm{cm}^{3}$ for both 
soils, the $18.5 \mathrm{~L}$ pots were filled in three lifts. Each lift had a thickness of $12.1 \mathrm{~cm}$ and 25 blows were applied to each lift, with a total of 75 blows per pot. To achieve a bulk density value of $1.4 \mathrm{~g} / \mathrm{cm}^{3}$ for both soils, the $18.5 \mathrm{~L}$ pot was filled in seven lifts. Each layer had a thickness of $5.2 \mathrm{~cm}$ and 200 blows were applied to each lift, with a total of 1,400 blows per pot.

Soil bulk density was measured using undisturbed samples collected from the pots using the clod method (Brasher et al. 1966; Blake and Hartge 1986) (Table 1).

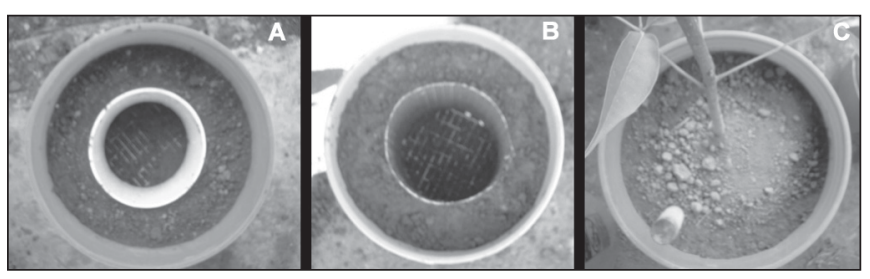

Figure 2. (a) Experimental pot with PVC pipe inside the metallic mesh, (b) the experimental pot without the PVC pipe, and (c) after the tree was transplanted in the experimental pot, same soil type was used to fill out the empty space inside the metallic pot.

\section{Seedling Planting}

Seedlings of same height $(47 \mathrm{~cm})$ for three species were potted in the inner pot created with metallic mesh. The empty space in the metallic mesh pot was filled with the same soil type but not compacted. Seedlings were placed randomly into the growing area with a spacing of $30 \mathrm{~cm} \times 60 \mathrm{~cm}$. The experiment lasted six months (August 2003-February 2004), during which time the trees received only natural rainfall and full sunlight. Every two months, 36 trees (two replicates per species-soil-compaction-treatment) were harvested. The following morphological variables were measured: tree height, shoot diameter, leaf number, foliar area, leaf, shoot, and root dry weights, and leaf color (determined using a Munsell Chart, Kollmorgen Instruments Corporation 1977).

\section{Statistical Analysis}

For each species, bulk density combination, and soil type, six pots were established. Every two months, 36 trees (two replicates per species-soil-compaction-treatment) were harvested. The data were analyzed using analysis of variance procedure PROC MIXED within SAS v.9.1.3 (SAS Institute Inc., Cary, NC). Soil and treatments were considered fixed effects and time and replicates were considered random effects. Means were separated using (Tukey test) mean separation test at the alpha $<0.05$ level of significance.

Table 1. Bulk density of two soils under different levels of compaction using clod method.

\begin{tabular}{lll}
\hline Soil & Compaction level & Bulk density $\left(\mathrm{g} / \mathrm{cm}^{3}\right)^{2}$ \\
\hline Sandy clay loam & Control & $1.07 \pm 0.25$ \\
& Intermediate & $1.20 \pm 0.01$ \\
& High & $1.40 \pm 0.02$ \\
Clay & Control & $1.05 \pm 0.01$ \\
& Intermediate & $1.22 \pm 0.26$ \\
& High & $1.42 \pm 0.02$ \\
\hline
\end{tabular}

${ }^{\mathrm{z}}$ Means and standard errors are listed to indicate soil compaction level and soil type variability.

\section{RESULTS}

\section{Tree Height}

Bottle brush grew rapidly during the first four months (from $47 \mathrm{~cm}$ to $116 \mathrm{~cm}$ ) but thereafter grew slowly, achieving a final height of $126 \mathrm{~cm}$. Trumpet bush and pink trumpet grew rapidly during the first two months (an increase in height of $91 \mathrm{~cm}$ and $84 \mathrm{~cm}$, respectively), but thereafter grew slowly, achieving final heights of $96 \mathrm{~cm}$ and $83 \mathrm{~cm}$, respectively. There was a significant effect of compaction for bottle brush and trumpet bush, but not for pink trumpet (Table 2). Bottle brush was taller at high and intermediate levels of compaction compared with control. Trumpet bush, had greater height under control treatment which represent looser soils (Figure 3). Also, trumpet brush has greater height under sandy clay loam soils compared with clay soils (Table 1). There was a signicant effect of soil type for trumpet bush but not for bottle brush or pink trumpet. Trumpet bush was taller for sandy clay soils compared with clay soils. The compaction and soil type interaction was not significant for any species.

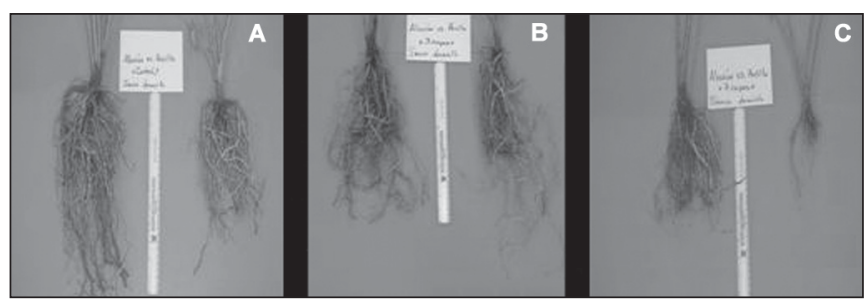

Figure 3. Root system of trumpet bush [Tecoma stans (L.)] harvested six month after planting on three compaction levels in both soils. The root systems located at left side, represent the trees planted on sandy clay loam, and the root systems located at the right side, represent clay soil: (a) control, (b) three layers $\left(D_{b} \approx 1.15 \mathrm{~g} / \mathrm{cm}^{3}\right)$, and $(c)$ seven layers $\left(D_{b}=1.4 \mathrm{~g} / \mathrm{cm}^{3}\right)$.

\section{Shoot Response}

\section{Shoot diameter}

There was a significant effect of compaction for trumpet bush, but not for bottle brush and pink trumpet tree species (Table $2)$, on shoot diameter. Trumpet bush had greater shoot diameter at control $(6 \mathrm{~cm})$ and intermediate level of compaction $\left(D_{b}=1.2 \mathrm{~g} / \mathrm{cm}^{3}\right)(4.8 \mathrm{~cm})$ compared with high level of compaction $\left(D_{b}=1.4 \mathrm{~g} / \mathrm{cm}^{3}\right)(1.9 \mathrm{~cm})$. There was a significant effect of soil type for trumpet bush and bottle brush trees planted in sandy clay soil compared with clay soils (Table 2). Soil type was not significant for pink trumpet. The compaction and soil type interaction was not significant for any species.

\section{Shoot dry weight}

There was a significant effect of compaction for trumpet bush, but not bottle brush and pink trumpet tree species (Table 2), on shoot dry weight. Trumpet bush trees growing in control and intermediate level of compaction had greater shoot dry weight $\left(D_{b}=1.2 \mathrm{~g} / \mathrm{cm}^{3}\right)$ compared with high level of compaction $\left(D_{b}=\right.$ $1.4 \mathrm{~g} / \mathrm{cm}^{3}$ ) (Table 2). There was a significant effect of soil type for trumpet bush, but not for bottle brush and pink trumpet tree species. Trumpet bush had greater shoot dry weight when growing in sandy clay loam, almost twice the dry weight com- 
Table 2. Morphological properties of bottle brush, trumpet bush, and pink trumpet grown on two soils under different levels of compaction.

\begin{tabular}{|c|c|c|c|c|c|c|c|c|}
\hline Species & & $\begin{array}{l}\text { Height } \\
(\mathrm{cm})\end{array}$ & $\begin{array}{l}\text { Shoot diameter } \\
(\mathrm{cm})\end{array}$ & $\begin{array}{l}\text { Leaf } \\
\text { number }\end{array}$ & $\begin{array}{l}\text { Shoot dry } \\
\text { weight }(\mathrm{g})\end{array}$ & $\begin{array}{l}\text { Root dry } \\
\text { weight }(\mathrm{g})\end{array}$ & $\begin{array}{l}\text { Leaf dry } \\
\text { weight }(\mathrm{g})\end{array}$ & $\begin{array}{l}\text { Leaf area } \\
\left(\mathrm{cm}^{2}\right)\end{array}$ \\
\hline \multicolumn{9}{|c|}{ Bottle brush } \\
\hline Compaction & $\operatorname{Pr}>\left(\mathrm{SE}^{\mathrm{y}}\right)$ & $(16.5)^{x}$ & NS & NS & NS & NS & NS & NS \\
\hline Control & & 94.5 & 4.8 & 733 & 25.9 & 16.1 & 18.2 & 731 \\
\hline Intermediate & & 100 & 4.7 & 867 & 23.8 & 15.2 & 16.3 & 1064 \\
\hline High & & 124 & 4.2 & 988 & 30.1 & 13.7 & 21.1 & 1007 \\
\hline Soil & $\operatorname{Pr}>\left(\mathrm{SE}^{\mathrm{y}}\right)$ & NS & $(0.85)^{x}$ & $(243)^{\mathrm{w}}$ & NS & $(5.9)^{x}$ & $(3.6)^{x}$ & $(280)^{\mathrm{w}}$ \\
\hline Sandy clay 1 & & 105 & 5.1 & 1209 & 32.3 & 18.5 & 23.6 & 1207 \\
\hline Clay & & 107 & 4.1 & 516 & 20.9 & 11.5 & 13.5 & 661 \\
\hline \multicolumn{9}{|c|}{ Trumpet bush } \\
\hline Compaction & $\operatorname{Pr}>\left(\mathrm{SE}^{\mathrm{y}}\right)$ & $(8.7)^{\mathrm{w}}$ & $(0.57)^{\mathrm{w}}$ & $(24.3)^{x}$ & $(6.1)^{x}$ & $(5.1)^{\mathrm{w}}$ & NS & NS \\
\hline Control & & 96.4 & 6.0 & 95.9 & 20.1 & 26.5 & 23.8 & 1443 \\
\hline Intermediate & & 83.2 & 4.8 & 84.1 & 24.4 & 22.0 & 20.2 & 1083 \\
\hline High & & 30.4 & 1.9 & 34.8 & 8.1 & 6.5 & 4.9 & 582 \\
\hline Soil & $\operatorname{Pr}>\left(\mathrm{SE}^{\mathrm{y}}\right)$ & $(7.1)^{\mathrm{x}}$ & $(0.48)^{x}$ & $(23)^{x}$ & $(5.7)^{\mathrm{w}}$ & $(4.7)^{\mathrm{w}}$ & NS & $(465)^{x}$ \\
\hline Sandy clay 1 & & 81 & 5.1 & 92.5 & 24.0 & 24.1 & 22.5 & 1474 \\
\hline Clay & & $59 *$ & 3.4 & 50.7 & 11.1 & 12.6 & 10.1 & 598 \\
\hline \multicolumn{9}{|c|}{ Pink trumpet } \\
\hline Compaction & $\operatorname{Pr}>\left(\mathrm{SE}^{\mathrm{y}}\right)$ & NS & NS & NS & NS & NS & $(12.3)^{x}$ & NS \\
\hline Control & & 81.4 & 7.8 & 10.9 & 35.3 & 35.9 & 27.8 & 1504 \\
\hline Intermediate & & 81.3 & 6.4 & 11.4 & 35.3 & 37.2 & 37.0 & 1610 \\
\hline High & & 79.6 & 7.1 & 9.8 & 27.5 & 25.1 & 17.7 & 1061 \\
\hline Soil & $\operatorname{Pr}>\left(\mathrm{SE}^{\mathrm{y}}\right)$ & NS & NS & $(1.9)^{x}$ & $(7.2)^{x}$ & $(5.3)^{x}$ & $(12.1)^{\mathrm{w}}$ & $(333)^{x}$ \\
\hline \multicolumn{2}{|c|}{ Sandy clay loam } & 82.8 & 7.3 & 12 & 39.2 & 37.6 & 35.0 & 1761 \\
\hline Clay & & 78.8 & 6.9 & 9.4 & 26.2 & 28.0 & 20 & 1023 \\
\hline
\end{tabular}

${ }^{\mathrm{z}}$ Means and standard errors are listed to indicate species soil-compaction and soil type variability.

$\mathrm{SE}=$ standard error

$\mathrm{SE}^{\mathrm{y}}=$ only shown for significant effects

${ }^{\times} P<0.05$; all compaction level ${ }^{\mathrm{x}}$ soil type interactions were NS and are not shown

w $P<0.01$

pared to plants growing in clay soil (Table 2). The compaction and soil type interaction was not significant for any species.

\section{Root Response}

\section{Root dry weight}

There was a significant effect of compaction for trumpet bush, but not for bottle brush and pink trumpet tree species (Table 2 ), regarding root dry weight. Trumpet bush had greater root dry weight in control and intermediate levels of compaction $\left(\mathrm{D}_{\mathrm{b}}=1.2 \mathrm{~g} / \mathrm{cm}^{3}\right)$ compared with high level of compaction $\left(D_{b}=1.4 \mathrm{~g} / \mathrm{cm}^{3}\right)$ (Table 2). The three tree species have greater root dry weight when grown in sandy clay loam compared to trees grown in clay soil (Table 2). The compaction and soil type interaction was not significant for any species.

Figure 3 (Trumpet bush), Figure 4 (Bottle brush), and Figure 5 (Pink trumpet) show the visual characteristics of the root systems of the study species at six months of growth. Figure 6 shows more root density for the trumpet bush planted in sandy clay loam soil. When the bulk density increased, the root system appeared thinner and shorter. All trumpet bush trees planted in clay soil at bulk density of $1.4 \mathrm{~g} / \mathrm{cm}^{3}$ died.

Bottle brush tree roots grown in sandy clay loam appeared numerous with greater root density compared with the trees planted on clay soil (Figure 4). The roots of the trees planted on clay soil looked thinner, scarcer, and shorter.
Pink trumpet tree roots were the only ones that showed circling roots (Figure 5), a common effect found in trees grown in containers. The roots of the trees planted on control and intermediate compaction level $\left(D_{b}=1.2 \mathrm{~g} / \mathrm{cm}^{3}\right)$ on sandy clay loam, showed thicker roots compared with the trees on clay soil.

\section{root:shoot ratio}

For bottle brush planted on sandy clay loam soil in the control and intermediate compaction level $\left(D_{b}=1.2 \mathrm{~g} / \mathrm{cm}^{3}\right)$, the root:shoot ratio was 1:4; for all three trees planted on clay soil the ratio was 1:3. However, the root:shoot ratio of trumpet bush and pink trumpet was also affected by harvest time.

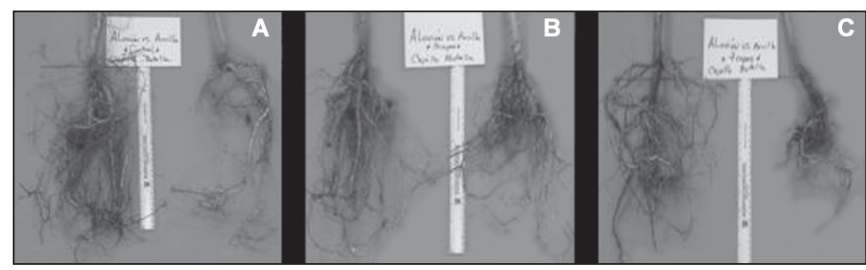

Figure 4. Root system of bottle brush [Callistemon citrinus (Stapf)] harvested six months after planting on three treatments in both soils. The root systems located at left side, represent the trees planted on sandy clay loam, and the root systems located at right side, represent clay soil: (a) control, (b) three layers $\left(D_{b} \approx 1.15 \mathrm{~g} / \mathrm{cm}^{3}\right)$, and $(c)$ seven layers $\left(D_{b}=1.4 \mathrm{~g} / \mathrm{cm}^{3}\right)$. 
The study authors observed a reduction of the ratio at six months after transplanting in both soil types, suggesting increasing root support for plants of a given size over time.

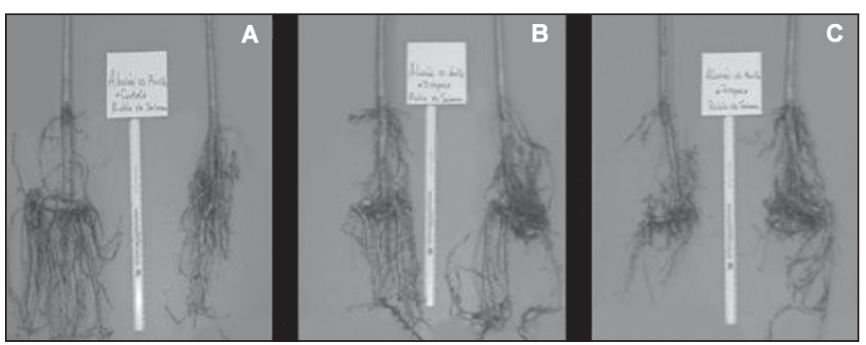

Figure 5. Root system of pink trumpet [Tabebuia rosea (Bertol.)] harvested six months after planting on three treatments in both soils. The root systems located at left side, represent the trees planted on sandy clay loam, and the root systems located at right side, represent clay soil: (a) control, (b) three layers $\left(D_{b} \approx 1.15 \mathrm{~g} / \mathrm{cm}^{3}\right)$, and $(c)$ seven layers $\left(D_{b}=1.4 \mathrm{~g} / \mathrm{cm}^{3}\right)$.

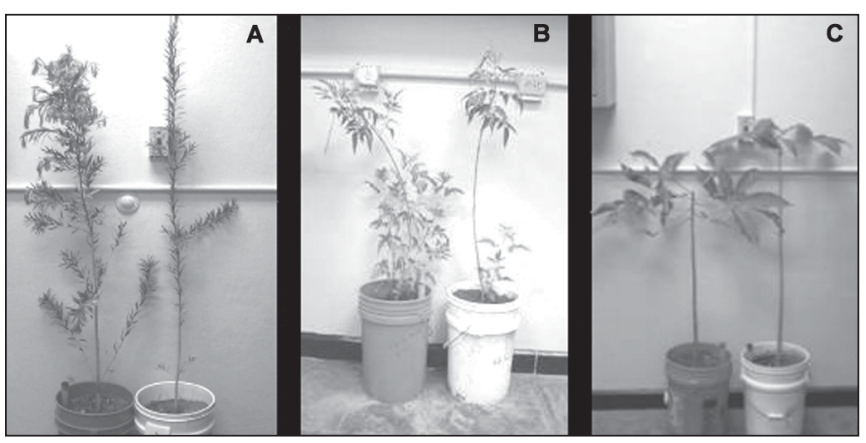

Figure 6. Visual comparisons of leaf number of trees harvested six months after planting. The visual comparison of leaf number by tree species and soil type. Trees located on left side, were planted in sandy clay loam, and on right side, in clay soil: (a) bottle brush, (b) trumpet bush, and (c) pink trumpet.

\section{Leaf Response}

\section{Leaf number}

There was a significant effect of compaction on leaf number for trumpet bush, but not for bottle brush and pink trumpet. Trumpet bush species showed greater root dry weight for control and intermediate compaction level $\left(\mathrm{D}_{\mathrm{b}}=1.2 \mathrm{~g} / \mathrm{cm}^{3}\right)$ treatment compared with high level of compaction (Table 2). The three tree species had greater leaf number when they grew on sandy clay loam compared to trees growing in clay soil (Table 2). Bottle brush growing in sandy clay loam soil had twice the number of leaves compared with the same species growing in clay soil (Table 2). The compaction and soil type interaction was not significant for any species.

Visual results displayed in Figure 6a show bottle brush planted in both soils had a greater leaf number compared with trumpet bush and pink trumpet. The three tree species exhibited more leaves in the sandy clay loam soil six month after transplanting (Figure 6a-Figure 6c). However, a reduction of leaf number was found for all three species at six months after transplanting due to coinciding with the dry season.

\section{Leaf dry weight}

There was a significant effect of soil compaction on leaf dry weight for trumpet bush, but not for bottle brush and pink trumpet. Trumpet bush species showed greater leaf dry weight under control and intermediate compaction level $\left(\mathrm{D}_{\mathrm{b}}=1.2 \mathrm{~g} / \mathrm{cm}^{3}\right)$ treatment compared with high level of compaction (Table 2). The three tree species had greater leaf dry weight when growing in sandy clay loam compared to trees growing in clay soil (Table 2). The compaction and soil type interaction was not significant for any species.

Also a reduction in dry weight for trumpet bush and pink trumpet at six months after transplantation was observed, but for bottle brush an increase in leaf dry weight occurred.

\section{Leaf area}

Soil compaction as a main effect showed no signicant difference for leaf area between treatments on the three tree species. However, the three tree species planted in sandy clay loam soil showed a greater mean foliar area compared to plants growing in sandy clay loam (Table 2). The compaction and soil type interaction was not significant for any species. For all species, there were no significant differences between the tree species, soil type, or compaction, in leaf color. The color remained dark green to green yellow.

\section{DISCUSSION}

Bottle brush and trumpet bush showed significant difference in height as a function of soil density, but there were no differences with pink trumpet. Smith et al. (2001) obtained similar results for Eucalyptus ficifolia, Corymbia maculata, and Agonis flexuosa. Small and McCarthy (2002) found Elymus hystrix was not affected by level of compaction.

Data from this experiment showed how shoot diameter was affected by soil type and level of compaction, especially for the trumpet bush species. Pan and Bassuk (1985) found soil compaction limits growth, shoot diameter, and shoot dry weight. This occurs because of reduction in root growth in limited volumes of soil, reducing the water holding capacity. However, other studies emphasize shoot diameter reduction is a combined response to mechanical impedance and an alteration in production of root synthesizer hormones such as gibberellins and cytokines (Krizek and Dubik 1987).

The shoot dry weight was affected on all plantings in clay soils at bulk density of $1.4 \mathrm{~g} / \mathrm{cm}^{3}$ but was statistically different for trumpet bush. A reduction in the shoot dry weight of Eupatorium rugosum planted in high levels of compaction was reported by Small and McCarthy (2002) who found, as did Kjelgren and Clark (1993) when Liquidambar styraciflua was planted in small volumes of clay loam soils.

Even though there was no significant interaction for soil compaction level and soil type for root dry weights, the trees planted on sandy clay loam for control treatments and bulk density of 1.2 $\mathrm{g} / \mathrm{cm}^{3}$ exhibited greater dry root weight compared with the trees planted on clay soil. Grabosky and Bassuk (1996) found that root penetration and root biomass of Quercus robur planted in clay loam soils decreased by $50 \%$ at bulk densities higher than $1.4 \mathrm{~g} /$ $\mathrm{cm}^{3}$. Smith et al. (2001) found a $60 \%$ reduction in root growth of Corymbia maculata, Lophostemon confertus, Agonis flexuosa, and Eucalyptus ficifolia in soil compacted a to a bulk density of $1.4 \mathrm{~g} / \mathrm{cm}^{3}$ or higher. Costello et al. (1997) found similar results 
for Populus nigra and Fraxinus oxycarpa trees. In contrast, Barker (1995) found Celtis australis and Prunus serotina growing in sandy clay loam had deep root systems in intermediate bulk density soils. Bulk densities of $1.4 \mathrm{~g} / \mathrm{cm}^{3}$ to $2.2 \mathrm{~g} / \mathrm{cm}^{3}$ are common in the urban environment, and have been shown to limit root growth (Patterson 1977; Alberty et al.1984; Craul 1992; Randrup 1998).

Reduction in the number of leaves results from: 1) soil type used, 2) heat stress during the dry months, reducing the available water in the soil and increasing the evapotranspiration, and 3) damage by insects that ate the leaves. Cregg and Dix (2001) reported Quercus rubra and Fraxinus pennsylvanica suffered from heat stress in the hottest months of the year in urban areas.

A reduction of the root:shoot ratio during the dry season (six months after planting) in both soil types was found in this study. Similar reduction in growth and root:shoot ratio was observed by Neal and Whitlow (1997) in seedlings that were not irrigated in dry seasons. Reductions in foliar leaf area may be due to heat stress effects. Svihra et al. (1993) observed that the growth of Sequoia sempervirens was affected by heat stress. The symptoms seen on trees were leaf fall, leaf curl and in extreme cases, death.

\section{CONCLUSIONS}

The results from this study show that compaction affects the growth characteristics of all three species used-bottle brush and pink trumpet are affected mainly by soil type, and trumpet bush growth is affected by soil type and soil compaction level. Bottle brush, an exotic species from Australia, showed a better response to all levels of compaction in both soils than pink trumpet and trumpet bush (natives of the Caribbean and Central America). All three species had better development on sandy clay loam soil. This response was expected because sandy clay loam texture is less compacted at the studied bulk densities. Results suggest the three tree species tested have the following order of tolerance to urban soil conditions: $C$. citrinus $>T$. rosea $>$ T.stans, in this study. A suggestion to urban foresters would be to give special attention to soil textural properties in establishing tree species in urban environments, in order to minimize the detrimental effect of compaction.

Acknowledgments. The authors wish to thank Dr. Eric Harmsen, Dr. Ramon Torres, and Dr. Miguel Pando for their support. Many thanks are also due to two anonymous reviewers of this journal and Mohan K. Wali; their comments improved the manuscript immensely.

\section{LITERATURE CITED}

Alberty, C.A., H.M. Pellet, and D.H. Taylor. 1984. Characterization of soil compaction at construction sites and woody plant response. Journal of Environmental Horticulture 2:48-53.

ATMOS CARIB. 2003. Research Center University of Puerto Rico Mayaguez Campus. <http://atmos.uprm.edu/>

Barker, P.A. 1995. Managed development of tree roots. I. Ultra-deep rootball and root barrier effects on European hackberry. Journal of Arboriculture 21(4):202-208.

Bassuk, N., and T. Whitlow. 1988. Environmental stress in street trees. Arboricultural Journal 12:195-201.

Blake, G.R., and K.H. Hartge. 1986. Bulk density. pp. 363-375. In: A. Klute (ed.) Methods of soil analysis. Part 1. Agronomy Monograph 9. ASA, Madison, WI.

Bradley, G.A. 1995. Urban Forest Landscapes. Integrating Multidisciplinary Perspectives. University of Washington Press, Seattle, WA.
Brasher, B.R., D.P. Franzmeier, V. Valassis, and S.E. Davidson. 1966. Use of saran resin to coat natural soil clods for bulk density and moisture retention measurements. Soil Science 70:351-362.

Chiapperini, G., and J.R. Donnelly. 1978. Growth of sugar maple seedlings in compacted soil. Fifth North American Forest Biology Workshop. pp. 196-200.

Craul, P.J. 1985. A description of urban soils and their desired characteristics. Journal of Arboriculture 11:330-339.

Craul, P. 1992. Urban Soil Landscape Design. John Wiley and Sons, New York, NY.

Cregg, B., and M.E. Dix. 2001. Tree moisture stress and insect damage in urban areas in relation to heat island effects. Journal of Arboriculture 27:8-17.

Costello, L., C.L. Elmore, and S. Steinmaus. 1997. Tree root response to circling root barriers. Journal of Arboriculture 23:211-218.

Day, S.D., and N.L. Bassuk. 1994. A review of the effects of soil compaction and amelioration treatments on landscape trees. Journal of Arboriculture 20:9-17.

Felt, E.J. 1965. Compactibility. pp. 401-413. In: C.A. Black (ed.), Methods of Soil Analysis, American Society of Agronomy, Madison, WI.

Foil, R.R., and C.W. Ralston. 1967. The establishment and growth of loblolly pine seedlings on compacted soils. Proceedings of the Soil Science Society of America 31:565-568.

Gentry, A.H. 1992. Bignoniaceae - Part II (Tribe Tecomeae). In: Organization for Flora Neotropica (ed.). Flora Neotropica Monograph.

Gilman, E.F., and D.G. Watson. 1993. Callistemon Citrinus: Red Bottlebrush. Fac Sheet ENH269. University of Florida

Grabosky, J., and N. Bassuk. 1996. Testing of structural urban tree soil materials for the use under pavement to increase street tree rooting volumes. Journal of Arboriculture 22:255-263.

Handreck, K.A., and N.D. Black. 1994. Growing Media for Ornamental Plants and Turf (2nd rev. ed.). New South Wales University Press, Kensington, Australia.

Jim, C.Y. 1998. Soil compaction at tree-planting sites in urban Hong Kong. pp 166-178. In: D. Neely and G.W. Watson (eds.). The Landscape below Ground II: Proceedings of an International Workshop on Tree Root Development in Urban Soils. International Society of Arboriculture, Champaign, IL.

Kelsey, P., and R. Hootman. 1990. Soil resource evaluation for a group of sidewalk street tree planters. Journal of Arboriculture 16:113-117.

Kjelgren, R., and J. Clark. 1993. Growth and water relations of Liquidambar styraciflua L. in an urban park and plaza. Trees 7:195-201.

Krizek, D.T., and S.P. Dubik. 1987. Influence of water stresses and restricted root volume on growth and development of urban trees. Journal of Arboriculture 13:47-55.

Kozlowski, T. 1985. Soil aeration, flooding, and tree growth. Journal of Arboriculture 3:161-167.

Lindsey, P., and N. Bassuk. 1991. Specifying soil volumes to meet the water needs of mature urban trees in containers. Journal of Arboriculture 17:141-149.

Little, E.L., Jr., and F.H. Wadsworth. 1964. Common trees of Puerto Rico and the Virgin Islands. Agriculture Handbook 249. U.S. Department of Agriculture, Forest Service. Washington, D.C. 548 p.

Materechera, S.A., A.R. Dexter, and A.M. Alston. 1991. Penetration of very strong soils by seedlings roots of different plant species. Plant and Soil 135:31-41.

Munsell ${ }^{\circledast}$ Color Charts for Plant Tissues. 1977. Macbeth Division of Kollmorgen Instruments Corporation, Baltimore, MD. 
Neal, B., and T. Whitlow. 1997. Using Tree Growth Rates to Evaluate Urban Tree Planting Specifications. Journal of Environmental Horticulture 15:115-118.

Pan, E., and N. Bassuk. 1985. Effects of soil type and compaction on the growth of Ailanthus altissima seedlings. Journal of Environmental Horticulture 3:158-162.

Patterson, J. 1977. Soil compaction-effects on urban vegetation. Journal of Arboriculture 3:161-167.

Patterson, J., J. Murray, and J. Short. 1980. The Impact of Urban Soils on Vegetation. Proceedings of the third conference of the Metropolitan Tree Improvement Alliance (METRIA). 3:33-56.

Randrup, T.B. 1997. Soil compaction on construction sites. Journal of Arboriculture 23(5):207-210.

Randrup, T.B. 1998. Soil compaction on construction sites. pp 146-153. In: D. Neely and G.W. Watson (eds.). The Landscape Below Ground II: Proceedings of an International Workshop on Tree Root Development in Urban Soils. International Society of Arboriculture, Champaign, IL.

Ruark, G.A., D.L. Mader, P.L.M. Veneman, and T.A. Tattar. 1983. Soil factors related to urban sugar maple decline. Journal of Arboriculture 9:1-6.

Salas-Estrada, J.B. 1993. Arboles de Nicaragua. Instituto Nicaragüense de Recursos Naturales y del Ambiente. Managua: IRENA.

Svihra, P., D.W. Burger, and R.W. Harris. 1993. Treeshelters for nursery plants can increase growth and be cost effective. California Agriculture 47(4):13-16.

Small, C.J., and B.C. McCarthy. 2002. Effects of simulated post-harvest light availability and soil compaction on deciduous forest herbs. Canadian Journal of Forestry Research 32:1753-1762.

Smith, K.D., P.B. May, and G. Moore. 2001. The influence of compaction and soil strength on the establishment of four Australian landscape trees. Journal of Arboriculture 27:1-7.

Tipton, J.L. 1994. Relative drought resistance among selected southwestern landscape plants. Journal of Agriculture 20:150-155.

Waring, R.H., and W.H. Schlesinger. 1985. Forest Ecosystems: Concepts and Management. Academic Press, Inc., Orlando, FL.

Whitmore, J.L., and G.S. Harsthorn. 1969. Literature review of common trees. Troptical Forestry Series, Contribution No. 8. Institute of Forest Products. College of Forest Resources, University of Washington, Seattle. 113 pp.

Zisa, R.P., H.G. Halverson, and B.B. Stout. 1980. Establishment and early growth of conifers on compact soils in urban areas. U.S.D.A. Forest Service, Paper NE-451, Radnor, PA.

\section{Rebecca Tirado-Corbalá (corresponding author) \\ The Ohio State University \\ School of Environment and Natural Resources \\ 210 Kottman Hall \\ 2021 Coffey Road \\ Columbus, Ohio 43210, U.S \\ rebeccatiradocorbala@gmail.com}

\section{Brian K.Slater}

The Ohio State University

School of Environment and Natural Resources

210 Kottman Hall

2021 Coffey Road

Columbus, Ohio 43210, U.S

slater.39@osu.edu
Résumé. Des semis d'arbres plantés dans bacs le long de trottoirs au sein d'environnements urbains ont produit une croissance et un développement restreints avec le temps. Ceci est le résultat d'un volume limité sol ainsi que de la compaction du sol qui entrave la disponibilité en éléments minéraux et le mouvement de l'eau. Au moyen d'espèces d'arbres communément employées en foresterie urbaine à Porto Rico, cette étude a été menée afin de déterminer leur réponse de croissance lorsqu'elles étaient plantées dans des sols compactés. Les semis de trois espèces ornementales d'arbres tropicaux - Tecoma stans (L.) Juss. ex Kunth, Callistemon citrinus (Curtis) Skeels et Tabebuia rosea dc. - ont été transplantés dans des pots avec des sols composés d'un loam argilo-sableux ou d'argile et selon trois degrés différents de compaction: groupe-témoin (aucune compaction), 1,2 g/ $\mathrm{cm}^{3}$ et 1,4 g/ $\mathrm{cm}^{3}$. La hauteur de la plante, le diamètre de la pousse, la coloration et le nombre de feuilles, la surface foliaire, ainsi que la masse sèche en racines, en pousses et en feuilles ont été mesurées sur deux plantes à chaque deux mois durant six mois. Toutes les espèces ont montré une meilleure croissance avec le loam argilo-sableux à $1,2 \mathrm{~g} / \mathrm{cm}^{3}$ de compaction ; après six mois, toutes les espèces ont montré une réduction du ratio pousse-racine. Lorsqu'ils étaient plantés dans le sol argileux à $1,4 \mathrm{~g} / \mathrm{cm}^{3}$, tous les semis de Tecoma stans sont morts à l'intérieur de deux mois. Aucune différence dans la coloration des feuilles n'a été observée entre les espèces à différents degrés de compaction. Le Callistemon citrinus a montré une plus faible perte de croissance avec l'augmentation du degré de compaction dans les deux types de sol.

Zusammenfassung. Sämlinge aus cntainern, die entlang von Gehwegen in einer urbanen Umgebung gepflanzt wurden, zeigen im Laufe der Zeit begrenztes Wachstum und Entwicklung. Das ist das Ergebnis einer begrenzten Pfanzgrube und Bodenverdichtung, welche die Verfügbarkeit von Wasser und Nährstoffen behindert. Unter Verwendung von häufig gepflanzten Baumarten in Puerto Rico, wurde in dieser Studied das Wachstum in verdichteten Böden untersucht. Sämlinge von drei ornamentalen, tropischen Baumarten wurden in Töpfe mit sandigem, tonigen Lehm oder Tonböden mit drei Verdichtungsgraden: $1.2 \mathrm{~g} / \mathrm{cm} 3$ und $1.4 \mathrm{~g} /$ cm3 sowie einer Kontrolle verpflanzt. Pflanzenhöhe, Triebduchmesser, Blattanzahl und Farbe, Blattfläche und Wurzeln, Trieb und Blatttrockengewicht wurden an zwei Pflanzen alle zwei Monate über sechs Monate gemessen. Alle Arten zeigten ein besseres Wchstum in sandigem Lehm bei $1,2 \mathrm{~g} / \mathrm{cm}^{3}$, nach sechs Monaten zweigten allen Pflanzen ein vermindertes Wurzel-Trieb-Verhältnis. Bei Pflanzungen in Ton mit 1,4 g/cm 3 starben alle Trompetenbüsche innerhalb von zwei Monaten. Es wurden keine Unterschiede in der Blattfarbe festgestellt. Der Zylinderputzer zeigte weniger Wachstumsrückgang bei zunehmender Bodenverdichtung

Resumen. La plantación de brinzales en contenedores a lo largo de aceras en ambientes urbanos mostró crecimiento y desarrollo restringidos en el tiempo. Esto es el resultado de volumen limitado de suelo y compactación que impide la disponibilidad de minerales y movimiento de agua. Con el uso de especies comunes en los bosques urbanos de Puerto Rico este estudio se condujo para determinar su respuesta en crecimiento cuando se plantan en suelos compactados. Los brinzales de especies de árboles tropicales Tecoma stans (L.) Juss. ex Kunth, Callistemon citrinus (Curtis) Skeels] y Tabebuia rosea dc. fueron trasplantados en contenedores con suelos areno-arcillo-limosos o arcillosos a tres niveles de compactación: control ( sin compactación), $1.2 \mathrm{~g} / \mathrm{cm} 3$ y $1.4 \mathrm{~g} / \mathrm{cm} 3$ de densidad, respectivamente. Se midió altura de la planta, diámetro de los brotes, número y color de las hojas, área foliar y pesos secos de raíces, brotes y hojas en dos plantas cada dos meses por seis meses. Todas las especies exhibieron mejor crecimiento en suelo areno-arcillo-limosos a $1.2 \mathrm{~g} / \mathrm{cm} 3$; después de seis meses, todas las especies mostraron una relación reducida raíz-brote. Cuando se plantaron en arcilla a $1.4 \mathrm{~g} / \mathrm{cm} 3$, todos los tecomas murieron en dos meses. No hubo diferencias en color de las hojas entre especies a diferentes niveles de compactación. Calistemo mostró menos supresión del crecimiento al incrementar los niveles de compactación en ambos suelos. 